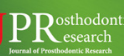 \\ Journal of Prosthodontic Research
}

\author{
Official Journal of the Japan Prosthodontic Society
}

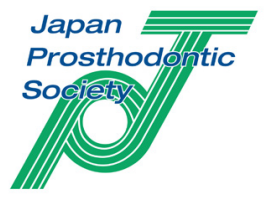

Review article

\section{Socket shield technique: A systemic review and meta-analysis}

\author{
Xi Lin, Yan Gao, Xianglong Ding, Xianghuai Zheng*
}

Affiliated Implantology center, Stomatological Hospital, Southern Medical University, Guangzhou, People’s Republic of China

\begin{abstract}
Purpose: The aim of the present study was to evaluate the clinical feasibility of the socket shield technique (SST).

Study selection: An electronic search of the PubMed, Cochrane Central Register of Controlled Trials, and Wiley Online Library databases, and a manual reference search for articles published up to September 2020 was conducted. Meta-analysis was performed to estimate marginal bone loss (MBL), changes in buccal bone width (cBBW), pink esthetic score (PES), implant stability quotient (ISQ), implant failure rate, and complication rate between SST and conventional immediate implant placement (IIP). All pooled analyses were based on random effects models.

Results: Sixteen relevant studies were ultimately selected by two independent reviewers: four randomized clinical trials (RCTs), four case-control studies, and eight retrospective studies. Meta-analysis revealed a trend toward lower MBL and cBBW and higher PES in the SST group. ISQ, implant failure rate, and complication rate were similar between the groups.

Conclusions: The included studies provided evidence that SST may be a feasible treatment option. However, this technique should not be used as a routine clinical protocol due to the lack of evidence-based consensus guidelines, large-scale RCTs, and long-term follow-up data. Therefore, there is an urgent need for well-conducted RCTs in this field.
\end{abstract}

Keywords: Socket shield technique, Aesthetic zone, Complication, Osseointegration

Received 5 November 2020, Accepted 19 May 2021, Available online 16 September 2021

\section{Introduction}

According to the published literature, the average thickness of the buccal bone width (BBW) in the anterior maxilla is $<1 \mathrm{~mm}$, and almost $50 \%$ of BBW values are $<0.5 \mathrm{~mm}[1]$. Therefore, such a thin facial bone wall, consisting mainly of bundle bone, appears to be prone to resorption following tooth extraction. The extent of bone resorption can be up to 2.6-4.5 $\mathrm{mm}$ and $0.4-3.9 \mathrm{~mm}$ in the horizontal and vertical directions, respectively, one year post-extraction[2].

Immediate implant placement (IIP) is becoming more popular among clinicians and patients owing to a reduction in surgery times, costs, and treatment cycles. Several studies have provided evidence that the success rate of IIP is similar to that of delayed implant placement[3,4]. However, some studies have found that IIP cannot prevent the absorption of alveolar bone and that it is associated with a higher frequency of soft tissue recession[3, 5-7].

To maintain soft and hard tissue contour and achieve long-term esthetic success, Hurzeler et al. published a proof-of-concept study of the socket shield technique (SST) in 2010[8]. This technique involves intentionally leaving a partial root membrane (RM) in the extraction socket during IIP. The authors reported a satisfactory outcome, given that no resorptive process in the BBW was noted and that implants were functionally loaded without any inflammation.

Since then, SST has become among the most controversial topics.

\footnotetext{
* Corresponding author at: Affiliated Stomatological Hospital, Southern Medical University, Guangzhou, People's Republic of China.

E-mail address: xianghuaizheng@yahoo.com (X. Zheng).

https://doi.org/10.2186/jpr.JPR_D_20_00262

1883-1958/C 2020 Japan Prosthodontic Society. All rights reserved.
}

Although most published studies have supported the feasibility of SST, many are clinical case reports, with little reference value and insufficient guidance. Some reviews[9-11] have described complications, surgical details, and histological findings of SST; however, to the best of our knowledge, no recent meta-analysis evaluating this technique has been published. Therefore, the aim of the present systematic review and metaanalysis of the relevant literature was to test the null hypothesis that there are no differences between SST and conventional IIP.

\section{Materials and methods}

\subsection{Objective}

This systematic review adhered to the Preferred Reporting Items for Systematic reviews and Meta-Analyses (i.e., PRISMA) statement and guidelines provided by the Cochrane Handbook for Systematic Reviews[12]. The focused question was elaborated using the PICO format (i.e., population, intervention, control, outcome) [13], as follows: population, patients who underwent implant placement; intervention, patients who underwent SST; control, patients who underwent conventional IIP; and outcome, primary outcomes included marginal bone loss (MBL) and changes in BBW (cBBW). The secondary outcomes were pink esthetic score (PES), implant stability quotient (ISQ), implant failure rate, and complication rate.

\subsection{Search strategy}

An electronic search of the PubMed, Cochrane Central Register of Controlled Trials, and Wiley Online Library databases was performed using specific search strings (Table 1), in addition to a manual search of the main implantology and periodontal journals, including Clinical 
Oral Implants Research, International Journal of Oral \& Maxillofacial Implants, Clinical Implant Dentistry and Related Research, Journal of Clinical Periodontology, and Journal of Periodontology, the bibliographies of previous reviews, and all relevant articles. Personal references were also searched. The final update of the search was performed in September 2020.

\subsection{Inclusion and exclusion criteria}

Eligibility criteria included studies based on the socket-shield principle, in which implants are placed in close proximity to, or in contact with, RM intentionally retained to preserve or promote buccal $/$ proximal/crestal bone. Article types included clinical human studies (either randomized or nonrandomized) that reported qualitative and quantitative parameters of MBL, cBBW, PES, ISQ, implant failure rate, and complication rate of SST and conventional IIP with no time restriction. Studies in which RM was not left intentionally to preserve or promote buccal/proximal/crestal bone, and implants were unintentionally placed in proximity or in contact with RM were excluded. Studies not published in English or Chinese, case reports, technical reports, finite element analyses, and review articles were also excluded.

\subsection{Quality assessment}

The included studies were independently screened by two examiners (XL and XHZ). The titles and abstracts of all studies retrieved in the online search were first scanned. The full-text of studies that fulfilled the inclusion criteria were then obtained. Full-text versions of studies that did not report sufficient data in the title and abstract needed to make a clear decision regarding fulfillment of the inclusion criteria were also obtained. Disagreements were resolved by discussion between the examiners. Kappa scores were determined to evaluate the level of inter-reviewer agreement.

The Cochrane Collaboration Risk of Bias tool was used to assess the risk of bias in randomized clinical trials (RCTs). "High risk of bias," "low risk of bias," or "unclear risk of bias" was assigned to each assessment item. The Joanna Briggs Institute (JBI) Critical Appraisal Checklist tool[14] was used to assess the quality of nonrandomized studies. Each component was rated as "yes," "no," "unclear," or "not applicable." The risk of bias classification was high, moderate, and low, corresponding to scores of 1-3, $4-6$, and $7-8$, respectively.

\subsection{Data analysis}

The primary outcomes assessed included MBL and cBBW. MBL was measured from the implant platform to the most crestal contact point between the implant and bone; $\mathrm{cBBW}$ was measured $0 \mathrm{~mm}$ from the crest. MBL and cBBW reflect bone changes in the vertical and horizontal directions, respectively.

Secondary outcomes included PES, ISQ, implant failure rate, and complication rate. PES is based on seven variables, each of which was assessed using a 2-1-0 score, with 2 being the best and 0 the poorest [15]. ISQ values were used as indicators of mechanical implant stability. They were obtained noninvasively using resonance frequency measurements. Theoretically, higher mechanical stiffness of the bone-implant interface is represented by higher ISQ value[16].

Complications included biological and mechanical complications. Biological complications are characterized by a process(es) that affects hard and/or soft tissues; technical complications include mechanical damage to the implant and its suprastructures. Implant failure included failure of osseointegration and fracture of the implant. For all categories, the number of events was recorded.

MBL, cBBW, and PES were divided into two subgroups according to the observation time period; more specifically, 6 months and 12 months postsurgery. ISQ was measured and analyzed at two time points: immediately after surgery and before final restoration. Implant failure and complication rates were calculated as the implant-base level.
Table 1. Search Strategy.

\begin{tabular}{|c|c|c|}
\hline Database & Search Strategy & Results \\
\hline Pubmed & $\begin{array}{l}\text { (((("socket shield") OR ("root membrane")) OR ("residual } \\
\text { root")) OR ("retained root")) OR ("root fragment") AND } \\
\text { ((implant) OR ("ridge preservation")) OR ("guided bone } \\
\text { regeneration") }\end{array}$ & 106 \\
\hline $\begin{array}{l}\text { Cochrane } \\
\text { Central Register } \\
\text { of Controlled } \\
\text { Trials }\end{array}$ & $\begin{array}{l}\text { "socket shield" in All Text OR "root membrane" in All } \\
\text { rext OR "retained root" in All Text OR "root fragment" in } \\
\text { All Text OR "residual root" in All Text AND "implant" in } \\
\text { All Text OR "ridge preservation" in All Text OR "guided } \\
\text { bone regeneration" in All Text }\end{array}$ & 41 \\
\hline $\begin{array}{l}\text { Wiley online } \\
\text { library }\end{array}$ & $\begin{array}{l}\text { "'socket shield" OR "root membrane" OR "retained } \\
\text { root" OR "root fragment" OR "residual root"" anywhere } \\
\text { and "implant OR " ridge preservation" OR "guided bone } \\
\text { regeneration"" anywhere }\end{array}$ & 469 \\
\hline
\end{tabular}

\subsection{Data analysis}

Two of the authors (XL and XHZ) also performed data synthesis. The following data were extracted from the articles included in the current study: year of publication; study type; patient and implant size; implant site and details; details regarding the type of intervention; details regarding the outcomes reported; and follow-up period.

The meta-analysis was performed using Review Manager version 5.3.2 (The Nordic Cochrane Center, The Cochrane Collaboration, Copenhagen, Denmark, 2014). Due to the small number of articles, publication bias could not be assessed via funnel plots; as such, forest plots were formulated to report the outcome. MBL, cBBW, PES, and ISQ are expressed as mean difference (MD) with corresponding 95\% confidence interval (CI) using the random effects model. Complication and implant failure rates were recorded as dichotomous outcomes, and expressed as risk ratio (RR) with corresponding $95 \%$ CI under the random effects model. Differences with $\mathrm{P}<0.05$ were considered to be statistically significant. The $\mathrm{I}^{2}$ statistic was used to express the percentage of total variation across studies due to heterogeneity, with $25 \%$ corresponding to low heterogeneity, $50 \%$ to moderate heterogeneity, and $75 \%$ to high heterogeneity.

\section{Results}

\subsection{Study characteristics}

A total of 616 articles were retrieved in the initial search, as shown in Fig. 1. The identification of duplicates and articles not related to the topic resulted in the removal of 479 studies (kappa $=0.75$ ). A review of the remaining titles, abstracts, and full-texts resulted 16 articles that were analyzed in the present study. There were four RCTs[17-20], four casecontrol studies (CCSs)[21-24], and eight retrospective studies (RSs)[25-32].

\subsection{Risk of bias assessment of the included studies}

A summary of the Cochrane Collaboration assessment of the four human RCTs is presented in Table 2. One study[17] was considered to have a lower risk of bias than the other three[18-20]. Among non-RCTs, one CCS[23] and one RS[29] were considered to have a moderate risk of bias, while the other nine were considered to have a low risk of bias (Table 3). More details are provided in Appendix 1.

\subsection{Characteristics and outcomes of the clinical studies}

The clinical characteristics reported in the included studies are summarized in Table 4 . For studies that only provided the clinical outcome of the SST group, a total of 511 implants (428 patients) were examined, with a maximum follow-up period of 10 years. Eight studies[17-24] that provided comparable clinical data for the SST group and conventional IIP group were included in the meta-analysis: 115 implants (111 patients) in the SST group; and 119 implants (117 patients) in the IIP group. 


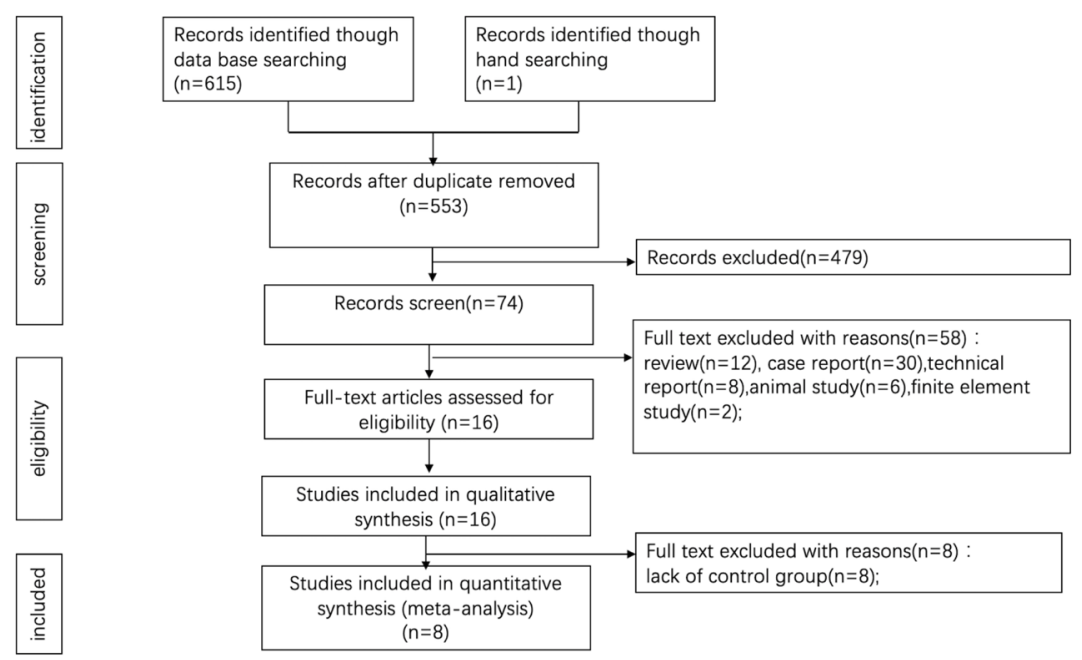

Fig. 1. Flowchart of selected and excluded studies for systematic review.

Table 2. Cochrane Collaboration's tool for assessing risk of bias of included human randomized clinical trials.

\begin{tabular}{|c|c|c|c|c|c|c|c|c|}
\hline & \multicolumn{3}{|c|}{ Selection bias } & \multirow[b]{2}{*}{$\begin{array}{l}\text { Free of } \\
\text { performance bias }\end{array}$} & \multirow[b]{2}{*}{$\begin{array}{l}\text { Free of } \\
\text { detection bias }\end{array}$} & \multirow[b]{2}{*}{$\begin{array}{l}\text { Free of } \\
\text { attrition bias }\end{array}$} & \multirow[b]{2}{*}{$\begin{array}{l}\text { Free of } \\
\text { exporting bias }\end{array}$} & \multirow[b]{2}{*}{$\begin{array}{l}\text { Free of } \\
\text { Other bias }\end{array}$} \\
\hline & Study design & $\begin{array}{l}\text { Random sequence } \\
\text { generation }\end{array}$ & $\begin{array}{l}\text { Allocation } \\
\text { concealment }\end{array}$ & & & & & \\
\hline Dalia $2017^{[20]}$ & $\mathrm{RCT}$ & Unclear & Unclear & Unclear & Unclear & Low & Low & Unclear \\
\hline Bramaiti $2018^{[17]}$ & $\mathrm{RCT}$ & Low & Low & Low & Low & Low & Low & Unclear \\
\hline Sun $2019^{[18]}$ & $\mathrm{RCT}$ & Low & Unclear & Unclear & Unclear & Low & Low & Unclear \\
\hline Ahmed $2020^{[19]}$ & RCT & Unclear & Low & Unclear & Unclear & Low & Low & Unclear \\
\hline
\end{tabular}

Table 3. The JBI critical appraisal checklist for assessing the quality of nonrandomized studies.

\begin{tabular}{|c|c|c|c|c|c|c|c|c|c|c|c|}
\hline Name & $\begin{array}{l}\text { Were there } \\
\text { clear criteria } \\
\text { for inclusion } \\
\text { in the case } \\
\text { series? }\end{array}$ & $\begin{array}{l}\text { Was the } \\
\text { condition } \\
\text { measured in } \\
\text { a standard, } \\
\text { reliable } \\
\text { way for all } \\
\text { participants } \\
\text { included in th } \\
\text { case series? }\end{array}$ & $\begin{array}{l}\text { Were valid } \\
\text { methods } \\
\text { used for } \\
\text { identification } \\
\text { of the } \\
\text { condition for } \\
\text { all participants } \\
\text { eincluded in the } \\
\text { case series? }\end{array}$ & $\begin{array}{l}\text { Did the case } \\
\text { series have } \\
\text { consecutive } \\
\text { inclusion of } \\
\text { sparticipants? } \\
\text { e }\end{array}$ & $\begin{array}{l}\text { Did the case } \\
\text { series have } \\
\text { complete } \\
\text { inclusion of } \\
\text { participants? }\end{array}$ & $\begin{array}{l}\text { Was there clear } \\
\text { reporting of the } \\
\text { demographics } \\
\text { of the } \\
\text { participants in } \\
\text { the study? }\end{array}$ & $\begin{array}{l}\text { Was there } \\
\text { clear reporting } \\
\text { of clinical } \\
\text { information } \\
\text { of the } \\
\text { participants? }\end{array}$ & $\begin{array}{l}\text { Were the } \\
\text { outcomes } \\
\text { or follow- } \\
\text { up results of } \\
\text { cases clearly } \\
\text { reported? }\end{array}$ & $\begin{array}{l}\text { Was there } \\
\text { clear } \\
\text { reporting } \\
\text { of the } \\
\text { presenting } \\
\text { site } \\
\text { demographic } \\
\text { information? }\end{array}$ & $\begin{array}{l}\text { Was } \\
\text { statistical } \\
\text { analysis } \\
\text { appropriate? } \\
\text { c }\end{array}$ & Risk of bias \\
\hline $\begin{array}{l}\text { Hesham } \\
2018^{[22]}\end{array}$ & Yes & Yes & Yes & Yes & Unclear & Unclear & No & Yes & Yes & Yes & low \\
\hline $\begin{array}{l}\text { Shamita } \\
2019^{[23]}\end{array}$ & Yes & Yes & Yes & Unclear & Unclear & No & No & Yes & Yes & Yes & moderate \\
\hline $\mathrm{Xu} 2019^{[21]}$ & Yes & Yes & Yes & Yes & Unclear & Yes & Yes & Yes & Yes & Yes & low \\
\hline $\begin{array}{l}\text { Sandy } \\
2020^{[24]}\end{array}$ & Yes & Yes & Yes & Unclear & Unclear & Yes & Yes & Yes & No & Yes & low \\
\hline $\begin{array}{l}\text { Baumer } \\
2017^{[27]}\end{array}$ & Yes & Yes & Yes & Yes & Yes & Yes & Yes & Yes & Yes & Yes & low \\
\hline Zhu $2018^{[32]}$ & Yes & Yes & Yes & Yes & Unclear & Yes & Yes & Yes & Yes & Yes & low \\
\hline Yan $2019^{[25]}$ & Yes & Yes & Yes & Yes & Unclear & No & Yes & Yes & Yes & Yes & low \\
\hline Han $2018^{[26]}$ & Yes & Yes & Yes & Yes & Yes & Yes & Yes & Yes & Yes & Yes & low \\
\hline $\begin{array}{l}\text { Hinze } \\
2018^{[28]}\end{array}$ & Yes & Yes & Yes & Yes & Unclear & Yes & Yes & Yes & No & Yes & low \\
\hline $\begin{array}{l}\text { Siormpas } \\
2014^{[29]}\end{array}$ & Yes & Yes & Yes & Unclear & Unclear & No & Yes & Yes & No & Yes & moderate \\
\hline $\begin{array}{l}\text { Siormpas } \\
2018^{[30]}\end{array}$ & Yes & Yes & Yes & Yes & Unclear & Yes & Yes & Yes & Yes & Yes & low \\
\hline $\begin{array}{l}\text { Gluckman } \\
2017^{[31]}\end{array}$ & Yes & Yes & Yes & Unclear & Yes & Yes & Yes & Yes & No & Yes & low \\
\hline
\end{tabular}


The majority of studies included only the maxillary anterior region; however, three[26, 30-31] also included mandibular anterior sites. Eleven of 16 studies did not report gingiva biotype, while three did not limit the biotype[19, 26-27], and two recruited cases with a thick biotype[18, 21]. Eight studies[18, 19, 20, 22, 24, 26, 28, 30] accepted light smokers ( $\leq 10$ cigarettes/day).

All of the included studies left RM on the buccal side, and the thickness of RM ranged from 1 to $3 \mathrm{~mm}$, depending on the study. None of the included studies reported RM length. RM margins were mainly divided into three levels: $1 \mathrm{~mm}$ above the bone level[18, 21-22, 27-30]; bone level[19, 24-25, 31]; and $1 \mathrm{~mm}$ under bone level[17]. One study reported using an enamel matrix derivative[27] to prepare the RM. Six studies reported using bone graft materials to fill gaps between implants and $\mathrm{RM}[17-18,21-22,25,27]$, and five clearly reported that no graft was used to fill the gap[24, 26, 29, 30, 32].

A variety of implant brands were used in the included studies, including Thommen (Grenchen, Switzerland), MegaGen (Daegu, Korea), Straumann (Basel, Switzerland), Nobel Biocare (Zurich, Switzerland), Osstem (Seoul, Korea), Dentium (Cypress, CA, USA), Ankylos (Dentsply Sirona, York, PA, USA), Dual Implant (Titan Industries EG, Cairo, Egypt), and Euroteknika (Sallanches, France). The diameter and length of the implants varied among the studies. Eleven studies used non-functional immediate loading after surgery[17-19, 21, $22,24,26,28-30,32]$, three used delayed loading[20, 23, 25], and a single study used both[27]. The time from surgery to final restoration ranged from 2 to 6 months.

The most frequently reported complication was RM exposure $[19,24,31,32]$. Other complications included implant failure[24,30,31], RM migration[31], RM resorption[29], and infection[30.31]. The clinical outcomes are summarized in Table 5.

\subsection{META-ANALYSIS}

\subsection{1. $M B L$}

Overall, there was a trend toward lower MBL in the SST group: total, mean difference (MD) $-0.44(95 \%$ CI -0.56 to -0.31$), \mathrm{P}<0.0001, \mathrm{I} 2=$ $75 \%$; 6 months post-surgery, MD -0.46 (95\% CI -0.62 to -0.30$), \mathrm{P}<$ $0.00001, \mathrm{I}^{2}=80 \%$ ) (Fig. 2).

\subsection{2. $c B B W$}

Results of meta-analysis revealed that the SST group preserved the buccal bone profile better than the IIP group: total, MD $-0.19(95 \%$ $\mathrm{CI}-0.25$ to -0.13$), \mathrm{P}<0.00001, \mathrm{I}^{2}=88 \% ; 6$ months post-surgery, $\mathrm{MD}$ $-0.17(95 \%$ CI -0.24 to -0.10$), \mathrm{P}=0.01, \mathrm{I}^{2}=78 \%$; and 12 months postsurgery, MD -0.47 (95\% CI -1.11 to 0.17$), \mathrm{P}<0.00001, \mathrm{I}^{2}=96 \%$ ) (Fig. 3).

\subsubsection{PES}

Meta-analysis revealed higher PES in the SST group: total, MD 1.44 (95\% CI $0.80-2.07), \mathrm{P}<0.00001, \mathrm{I}^{2}=82 \% ; 6$ months post-surgery, MD 1.42 (95\% CI $0.28-2.57), \mathrm{P}<0.0001, \mathrm{I}^{2}=87 \%$; and 12 months postsurgery: MD 1.44 (95\% CI 0.60-2.27), $\mathrm{P}=0.001, \mathrm{I} 2=81 \%$ ) (Fig. 4).

\subsubsection{ISQ}

Both groups demonstrated good ISQ immediately after surgery and before final restoration, which facilitated suitability for immediate restoration and sufficient stability to accept final crown delivery: total, MD 1.92 (95\% CI 0.19-3.66); $\mathrm{P}=0.09 ; \mathrm{I}^{2}=51 \%$; immediately after surgery, MD 1.90 (95\% CI -0.80-4.59), $\mathrm{P}=0.08, \mathrm{I}^{2}=61 \%$; and before final restoration, MD $2.34(95 \%$ CI $0.20-4.48), \mathrm{P}=0.32, \mathrm{I}^{2}=1 \%$ ) (Fig. $5)$.

\subsubsection{Implant failure and complications}

Only one CCS [24] reported two implant failures (one in the SST group and one in the IIP group); as a result, only one study was analyzed. Both the SST and IIP groups exhibited low implant failure (Fig. 6) and complication (Fig. 7) rates. The difference was not significant between the groups (implant failure rate, RR 1.00 [95\% CI 0.07-14.90]; complication rate, RR 0.68 [95\% CI 0.18-2.54]; $\mathrm{P}=0.56 ; \mathrm{I}^{2}=9 \%$ ).

\section{Discussion}

In meta-analyses, the potential of bias is likely to be greater for nonrandomized CCSs than for RCTs. However, excluding the results from non-randomized studies would likely miss some important data[33]. To establish a solid foundation for causal inferences, therefore, additional data from non-randomized studies were included in the current study.

Based on findings from the current study, the implant survival rate in the SST group ranged from $97.3 \%$ to $100 \%$, and the incidence of complications varied from $0 \%$ to $19.5 \%$, which is similar to that of implant-supported single crowns after 5 years of functioning. Most implant failures and complications were reported in studies by Siormpas et al.[30] and Gluckman et al.[31]. These two studies included large cohorts with a long-term follow-up period of up to 10 years, thereby supporting the longterm success of SST.

Clinicians have attempted every method to prevent MBL and decrease absorption of the buccal bone plate[34-35]. The buccal bone-periodontal ligament (BB-PDL) complex is considered to be very important for maintaining alveolar ridge contour. When the tooth is extracted, this structure disappears, resulting in collapse of the residual bone tissue[36]. The present meta-analysis confirmed the hypothesis that implants treated with SST achieve a better and more stable hard profile compared with conventional IIP. Comparison of the included studies demonstrated a total of $0.44 \mathrm{~mm}$ less MBL and $0.19 \mathrm{~mm}$ less cBBW for implants treated with SST. A large number of animal studies and histological findings have shown that the BB-PDL complex could be well preserved using SST because the blood supply stemming from the periodontal ligament maintains buccal bone dynamics and contributes to long-term stability[37,38]. PDL also plays an important role in biological sealing. Once the natural PDL is missing, the defense mechanism around the implant is weakened, and there is a higher risk for bacterial invasion and subsequent bone resorption[39,40].

For esthetic assessment, hard tissue features, crown profile, and periimplant soft tissue stability should be considered. However, peri-implant soft tissue presents clinical challenges from an esthetic perspective. The most common reasons for esthetic failure include disharmonious mucosal color or texture, loss of interproximal papillae, and recession of the soft tissue level. Hence, soft tissue esthetic outcomes are of vital importance for achieving clinical esthetic success. The PES is an objective system for evaluating peri-implant soft tissues[15, 41]. The system is based on seven variables - namely, mesial and distal papilla, the level of soft tissue margin, the contour, color, and texture of the soft tissue, as well as the alveolar process deficiency. The highest possible score reflecting a perfect match of the peri-implant soft tissue with that of the reference tooth is 14 . In terms of the present study, the SST group exhibited a high PES, with an average of 11-13 points, which was $1.42-1.44$ points greater than that of the IIP group at 6 and 12 months after surgery, respectively. Because soft tissue contour mainly depends on the underlying anatomy, stable PES further confirmed the contribution of RM.

It is crucial to isolate the implant from the oral cavity; thus, nonsubmerged healing is necessary for both SST and IIP. Constructing a customized healing abutment or anatomical provisional crown is required. Because bone-implant contact is reduced in a fresh extraction socket, an adequate surgical protocol for achieving primary implant stability is fundamental. Currently, ISQ is often used to measure primary implant stability[16, 42]. From our investigation, both groups exhibited good ISQ immediately after surgery, thus indicating suitability for immediate restoration. Intraoperative ISQ in the SST group was slightly greater than that of the IIP group (mean, 1.90), suggesting that the presence of RM did not influence primary stability. After several months of healing, implant stability - which is first achieved from mechanical stability - progresses to biological stability. Increased ISQ indicates successful osteointegration.

Although SST is no longer considered to be an experimental technique, many aspects should be interpreted with caution. First, a clear consensus protocol for SST is lacking. There are numerous reasons for tooth extraction. In most of the included studies, for SST, the root did not have a 
Table 4. Characteristics of the included studies.

\begin{tabular}{|c|c|c|c|c|c|c|c|c|c|c|c|c|c|c|c|}
\hline Name & $\begin{array}{l}\text { Study } \\
\text { type }\end{array}$ & $\begin{array}{l}\text { Case } \\
\text { of SST } \\
\text { group } \\
\text { (Patient / } \\
\text { implant) }\end{array}$ & $\begin{array}{l}\text { Case of } \\
\text { IIP group } \\
\text { (Patient / } \\
\text { /implant) }\end{array}$ & age (y) & Area & $\begin{array}{l}\text { Inclusion } \\
\text { for } \\
\text { smokers }\end{array}$ & $\begin{array}{l}\text { Gingiva } \\
\text { biotype }\end{array}$ & Implant & $\begin{array}{l}\text { Implant } \\
\text { size (mm) }\end{array}$ & $\begin{array}{l}\text { Graft } \\
\text { material }\end{array}$ & $\begin{array}{l}\text { Position } \\
\text { of RM }\end{array}$ & $\begin{array}{l}\text { RM } \\
\text { preparation }\end{array}$ & $\begin{array}{l}\text { Immediate } \\
\text { loading }\end{array}$ & $\begin{array}{l}\text { Final } \\
\text { restoration } \\
\text { time }(\mathrm{m})\end{array}$ & $\begin{array}{l}\text { Follow-up } \\
\text { (m) }\end{array}$ \\
\hline $\begin{array}{l}\text { Dalia } \\
2017^{[20]}\end{array}$ & RCT & 10,10 & 10,10 & Mean 35 & MA & Yes & NM & Dentium & $\begin{array}{l}\mathrm{D}: 3.3-4.3 \\
\mathrm{~L}: 10-14\end{array}$ & NM & Buccal & NM & No & 4 & 7 \\
\hline $\begin{array}{l}\text { Bramaiti } \\
2018^{[17]}\end{array}$ & RCT & 20,20 & 20,20 & NM & MA & No & NM & NM & D: 4.5 & CopiOs & Buccal & $\begin{array}{l}1 \mathrm{~mm} \text { sub } \\
\text { crest }\end{array}$ & Yes & 6 & 36 \\
\hline $\begin{array}{l}\text { Sun } \\
2019^{[18]}\end{array}$ & RCT & 15,15 & 15,15 & $\geq 25$ & MA & Yes & Thick & Nobel & NM & $\begin{array}{l}\text { Bio-Oss } \\
\text { (gap } \geq 1 \mathrm{~mm})\end{array}$ & Buccal & $\begin{array}{l}1 \mathrm{~mm} \text { above } \\
\text { bone crest }\end{array}$ & Yes & 6 & 24 \\
\hline $\begin{array}{l}\text { Ahmed } \\
2020^{[19]}\end{array}$ & RCT & 16,20 & 18,20 & $\begin{array}{l}21-39 \\
\text { Mean:30.9 }\end{array}$ & MA & Yes & No limit & Dual & $\begin{array}{l}\text { D:3.3-3.7; } \\
\text { L:14-16 }\end{array}$ & ; NM & Buccal & $\begin{array}{l}\text { to the level } \\
\text { of bone crest }\end{array}$ & Yes & 6 & 6 \\
\hline $\begin{array}{l}\text { Hesham } \\
2018^{[22]}\end{array}$ & CCS & 10,10 & 10,10 & $\geq 18$ & MA & Yes & NM & NM & NM & $\begin{array}{l}\text { Bio-Oss } \\
\text { (gap } \geq 2 \mathrm{~mm})\end{array}$ & Buccal & $\begin{array}{l}1 \mathrm{~mm} \text { above } \\
\text { bone crest }\end{array}$ & Yes & 6 & 12 \\
\hline $\begin{array}{l}\text { Shamita } \\
2019^{[23]}\end{array}$ & $\mathrm{CCS}$ & 8,8 & 8,8 & $18-30$ & MA & NM & NM & NM & NM & NM & Buccal & $\begin{array}{l}\text { Subgingival } \\
\text { level }\end{array}$ & No & 4 & 12 \\
\hline $\mathrm{Xu} 2019^{[21]}$ & ${ }^{]} \mathrm{CCS}$ & 12,12 & 12,12 & $\begin{array}{l}25-53 \\
\text { Mean:38.0 }\end{array}$ & MA & No & Thick & $\begin{array}{l}\text { Nobel, } \\
\text { Osstem }\end{array}$ & NM & $\begin{array}{l}\text { Bio-Oss } \\
\text { (gap } \geq 2 \mathrm{~mm})\end{array}$ & Buccal & $\begin{array}{l}1 \mathrm{~mm} \text { above } \\
\text { bone crest }\end{array}$ & Yes & 6 & 12 \\
\hline $\begin{array}{l}\text { Sandy } \\
2020^{[24]}\end{array}$ & CCS & 20,20 & 20,20 & $\begin{array}{l}28-65 \\
\text { Mean:51 }\end{array}$ & MA & Yes & NM & Euroteknika & $\begin{array}{l}\text { D:3.5-5.0 } \\
\text { L:11-14 }\end{array}$ & No & Buccal & $\begin{array}{l}2 \mathrm{~mm} \text { thick; } \\
\text { to the level } \\
\text { of bone crest }\end{array}$ & Yes & 3 & 12 \\
\hline $\begin{array}{l}\text { Baumer } \\
2017^{[27]}\end{array}$ & RS & 10,10 & No & $\geq 25$ & MA & No & No limit & Thommen & NA & DBBM & Buccal & $\begin{array}{l}2-3 \mathrm{~mm} \\
\text { thick; } 1 \mathrm{~mm} \\
\text { above bone } \\
\text { level }\end{array}$ & $\begin{array}{l}6 \text { (Yes) } \\
4(\mathrm{No})\end{array}$ & 5 & 60 \\
\hline $\begin{array}{l}\text { Zhu } \\
2018^{[32]}\end{array}$ & RS & 9,10 & No & $27-62$ & MA & NM & NM & $\begin{array}{l}\text { Thommen, } \\
\text { Ankylos }\end{array}$ & $\begin{array}{l}\text { D:3.5-5.0 } \\
\text { L:11-14 }\end{array}$ & No & Buccal & $\begin{array}{l}1 \mathrm{~mm} \text { thick, } \\
4 \mathrm{~mm} \text { long; } \\
1 \mathrm{~mm} \text { above } \\
\text { bone crest }\end{array}$ & Yes & 3 & $12-48$ \\
\hline $\begin{array}{l}\text { Hinze } \\
2018^{[28]}\end{array}$ & RS & 15,17 & No & $\begin{array}{l}26-65 \\
\text { Mean:49 }\end{array}$ & MAMB & Yes & NM & Thommen & NM & NM & Buccal & $\begin{array}{l}1-2 \mathrm{~mm} \\
\text { thick; } \\
1 \mathrm{~mm} \text { above } \\
\text { bone crest }\end{array}$ & Yes & 4 & 3 \\
\hline $\begin{array}{l}\text { Han } \\
2018^{[26]}\end{array}$ & RS & 30,40 & No & $\begin{array}{l}20-82 \\
\text { Mean } 48\end{array}$ & MADA & Yes & No limit & Anyridge & $\begin{array}{l}D: 3.5-5.5 \\
L: 7-13\end{array}$ & No & Buccal & $\begin{array}{l}\geq 1.5 \mathrm{~mm} \\
\text { thick }\end{array}$ & Yes & 12 & 12 \\
\hline $\begin{array}{l}\text { Yan } \\
2019^{[25]}\end{array}$ & $\mathrm{RS}$ & 10,10 & No & $18-48$ & MA & No & NM & $\begin{array}{l}\text { Straumann, } \\
\text { Osstem, } \\
\text { Nobel, } \\
\text { Dentium }\end{array}$ & $\begin{array}{l}\text { D:3.3-4.1 } \\
\text { L:11.5-14 }\end{array}$ & $\begin{array}{l}\text { Bio-Oss } \\
\text { (gap } \geq 1 \mathrm{~mm})\end{array}$ & Buccal & $\begin{array}{l}\geq 1.5 \mathrm{~mm} \\
\text { thick; to the } \\
\text { level of bone } \\
\text { crest }\end{array}$ & $\begin{array}{l}\text { No } \\
\text { e }\end{array}$ & 6 & 12 \\
\hline $\begin{array}{l}\text { Siormpas } \\
2014^{[29]}\end{array}$ & RS & 46,46 & No & $\begin{array}{l}28-70 \\
\text { Mean:53 }\end{array}$ & MA & NM & NM & MegaGen & $\begin{array}{l}\text { D:4-5 } \\
\text { L:10-15 }\end{array}$ & No & Buccal & $\begin{array}{l}1 \mathrm{~mm} \text { thick, } \\
1 \mathrm{~mm} \text { above } \\
\text { bone crest }\end{array}$ & Yes & 3 & 60 \\
\hline $\begin{array}{l}\text { Siormpas } \\
2018^{[36]}\end{array}$ & RS & 182,250 & No & $\begin{array}{l}18-83 \\
\text { Mean:53.5 }\end{array}$ & MA DA & Yes & NM & MegaGen & $\begin{array}{l}\text { D:3.3-5.0 } \\
\text { L:8,5-15 }\end{array}$ & No & Buccal & $\begin{array}{l}1 \mathrm{~mm} \text { above } \\
\text { bone crest }\end{array}$ & Yes & $2-3$ & 120 \\
\hline $\begin{array}{l}\text { Gluckman } \\
2017^{[31]}\end{array}$ & RS & 128,128 & No & $\begin{array}{l}24-71 \\
\text { Mean:39 }\end{array}$ & MA DA & NM & NM & $\begin{array}{l}\text { MegaGen, } \\
\text { Ankylos, } \\
\text { Nobel }\end{array}$ & NM & NM & Buccal & $\begin{array}{l}\text { to the level } \\
\text { of bone crest }\end{array}$ & NM & NM & 48 \\
\hline
\end{tabular}

RS retrospective study; CCS case-control study; RCT randomized controlled trial;

MA: maxillary anterior; DA: mandibular anterior; MB: maxillary bicuspid

D: Diameter; L: length; RM: root membrane; NM not mention.

vertical fracture on the buccal side, and the subcrest horizontal fracture was also not allowed. Apical endodontic pathology is not an absolute contraindication. However, if the interface between the RM and implant is not thoroughly decontaminated, endotoxins, inflammatory cells, and bacterial deposits may become a potential source of infection and evoke an inflammatory response in the short or long term. No consensus statement has been published regarding the ideal RM dimensions in terms of length, thickness, or margin. Moreover, there is no consensus regarding the possible need to fill the gap with bone graft material nor the type of bone graft material suitable/optimal for SST. Second, the technique needs to be safe and repeatable because an inexperienced surgeon may produce adverse results and obscure the evaluation of its performance. The surgeon needs to be specially trained and possess a high degree of clinical skill because the surgical procedure requires more time and patience. Finally, although implant failure and complication rates were low in the current metaanalysis, some studies $[43,44]$ have reported a case series documenting late implant complications and failures after 4-10 years of loading, which indicates the potential long-term risks of SST. Complications such as
RM migration, exposure, or inflammation may lead to soft tissue defects, pocket formation, mucositis, and peri-implantitis. This may also lead to severe esthetic problems such as discoloration and recession of the soft tissues[30, 31, 45-47].

Despite the comprehensive data synthesis and extraction performed in the present study, some limitations should not be neglected. Due to the small number of articles, publication bias could not be assessed via funnel lots; thus, it is not known whether studies with a negative outcome may have altered the outcome. There were many differences among the included studies, such as differences in preparation of RM, gingiva biotype, and loading protocol, which may have led to heterogeneity in some outcomes. It was not possible to discriminate these factors for a more individualized analysis, and these confounding factors may possibly represent an obstruction to the true outcome. However, the number of available RCTs is limited, and most of the included studies reported a small number of cases with short follow-up periods. Only a few studies reported adverse effects or complications. Therefore, it is still recommended that SST not be used as a routine clinical protocol because the procedure is technique-sensitive and 
Table 5. Clinical outcome of included studies.

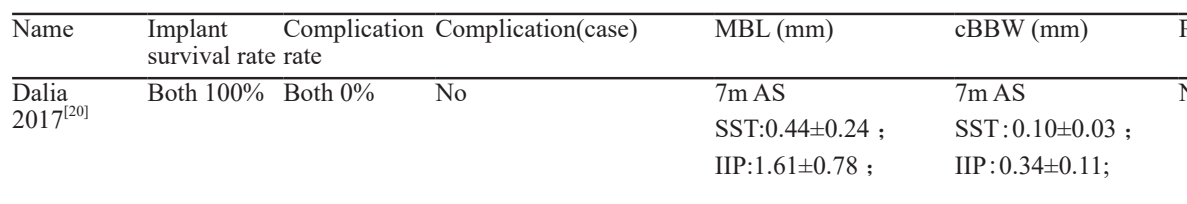

PES

$\begin{array}{ll}\text { ISQ } & \begin{array}{l}\text { Soft tissue } \\ \text { recession(mm) }\end{array} \\ \text { Immediate AS } & \mathrm{NM}\end{array}$

SST: $60.3 \pm 6.43$; NM

. $57.2 \pm 9.15$

$4 \mathrm{~m}$ AS

SST: $69.8 \pm 3.77$;

IIP : $65.6 \pm 5.66$;

\begin{tabular}{lllll}
\hline Bramaiti & Both $100 \%$ Both $0 \%$ & No & 6m AS & NM \\
$2018^{[17]]}$ & & & SST: $0.54 \pm 0.055 ;$ & \\
& & & IIP : $1.015 \pm 0.098 ;$ \\
\hline
\end{tabular}

$6 \mathrm{~m}$ AS

NM NM

SST: $12.3 \pm 0.86$;

IIP : $11.05 \pm 1.53$;

Sun $2019^{[18]}$ Both $100 \%$ Both $0 \% \quad$ No

Not clear

Not clear

$6 \mathrm{~m} \mathrm{AS}$

SST: $12.00 \pm 1.77$

Immediate AS $\quad 6 \mathrm{~m} \mathrm{AS}$

IIP: $11.73 \pm 1.67$

SST: $76.01 \pm 1.31$

SST:0.3 \pm 0.07

$12 \mathrm{~m} \mathrm{AS}$

IIP:75.56 \pm 1.07

IIP: $0.87 \pm 0.19$;

SST:12.20 1.57

$12 \mathrm{~m} \mathrm{AS}$

IIP: $11.53 \pm 1.73$

\begin{tabular}{|c|c|c|c|c|}
\hline \multirow[t]{2}{*}{$\begin{array}{l}\text { Ahmed } \\
2020^{[19]}\end{array}$} & Both $100 \%$ & SST: $5 \%$ & $\begin{array}{l}\text { SST:RM internal exposure } 6 \mathrm{~m} \mathrm{AS} \\
\text { (1) }\end{array}$ & $6 \mathrm{~m} \mathrm{AS}$ \\
\hline & & IIP:0\% & $\begin{array}{ll}\text { SST: } 0.34 \pm 0.12 \\
\text { IIP: } 0.77 \pm 0.35\end{array}$ & $\begin{array}{l}\text { SST: } 0.12 \pm 0.07 \\
\text { IIP: } 0.28 \pm 0.15\end{array}$ \\
\hline
\end{tabular}

$6 \mathrm{~m} \mathrm{AS}$

SST: $12 \pm 1.12 \quad$ SST: $68.6 \pm 3.81$

IIP: $8.85 \pm 1.51 \quad$ IIP: $66.4 \pm 5.64$

$6 \mathrm{~m}$ AS

SST: $76.7 \pm 3.49$

IIP : $75.0 \pm 4.4$

\begin{tabular}{lllll}
\hline Hesham & Both $100 \%$ & Both $0 \%$ & NM & 6m AS \\
$2018^{[22]}$ & & & SST:0.639 $\pm 0.116 ;$ \\
& & & IIP:0.979 $\pm 0.169 ;$ \\
& & & $12 \mathrm{~m}$ AS \\
& & & SST:0.693 $\pm 0.109 ;$ \\
& & & IIP: $1.064 \pm 0.240$ \\
\hline Shamita & NM & NM & NM & NM
\end{tabular}

$\mathrm{M}$

$6 \mathrm{~m} \mathrm{AS}$

NM

IIP: $1.09 \pm 0.22$;

2019

\begin{tabular}{llllll}
\hline Xu 2019 & Both 100\% & Both 0\% & No & NM & SST: \\
& & & IIP:0 \\
\hline $\begin{array}{l}\text { Sandy } \\
2020^{[2]]}\end{array}$ & SST:95\% & SST:15\% & $\begin{array}{l}\text { SST: RM exposure (2), } \\
\text { implant failure (1) }\end{array}$ & NM & NM
\end{tabular}

IIP:95\% IIP:30\% IIP: soft tissue recession

(5), implant failure (1)

SST:11.2 \pm 0.92 ;

IIP: $10.3 \pm 0.48$;

$12 \mathrm{~m} \mathrm{AS}$

SST:11.1 \pm 0.74 ;

IIP: $10.2 \pm 0.42$

$8 \mathrm{~m} \mathrm{AS}$

SST:0.03 \pm 0.025

NM

NM

IIP:0.156 \pm 0.029

$12 \mathrm{~m} \mathrm{AS}$

SST: $0.03 \pm 0.025$

IIP: $0.188 \pm 0.013$

$12 \mathrm{~m} \mathrm{AS} \quad 12 \mathrm{~m} \mathrm{AS} \quad$ NM NM

SST:0.04 $\pm 0.13 \quad$ SST: $13.25 \pm 0.75$;

IIP: $0.85 \pm 0.45$

$\begin{array}{lll}\text { IIP: } 95 \% & \text { IIP: } 30 \% & \begin{array}{l}\text { IIP: soft tissue recession } \\ \text { (5), implant failure (1) }\end{array}\end{array}$
IIP: $11.83 \pm 0.94$

NM $12 \mathrm{~m} \mathrm{AS} \quad$ NM

Han $2018^{[26]} 100 \% \quad 0 \% \quad \mathrm{~N}$

NM

NM

SST: $12.26 \pm 1.04$;

IIP : $9.63 \pm 1.34$

\begin{tabular}{ll} 
& \\
NM & $3 \mathrm{~m} \mathrm{AS}$ \\
& $-0.07 \pm 0.16$ \\
\hline NM & NM \\
& NM \\
\end{tabular}

mmediate AS NM

$72.9 \pm 5.9$

$12 \mathrm{~m} \mathrm{AS}$

$74.6 \pm 2.7$

\begin{tabular}{|c|c|c|c|c|c|c|c|c|}
\hline $\begin{array}{l}\text { Baumer } \\
2017^{[27]}\end{array}$ & $100 \%$ & $0 \%$ & No & $\begin{array}{l}\text { Mesial } 0.33 \pm 0.43 \text {, } \\
\text { Distal } 0.17 \pm 0.36\end{array}$ & NM & 12 & NM & $-0.33 \pm 0.23$ \\
\hline $\begin{array}{l}\text { Siormpas } \\
2014^{[2]]}\end{array}$ & $100 \%$ & $2 \%$ & RM resorption (1) & NM & NM & NM & NM & NM \\
\hline $\begin{array}{l}\text { Gluckman } \\
2017^{[31]}\end{array}$ & $96 \%$ & $19.50 \%$ & $\begin{array}{l}\text { Implant failure (5); } \\
\text { infection (3); } \\
\text { RM exposure (16); } \\
\text { RM migration (1); }\end{array}$ & NM & NM & NM & NM & NM \\
\hline $\begin{array}{l}\text { Siormpas } \\
2018^{[30]}\end{array}$ & $97.30 \%$ & $11.50 \%$ & $\begin{array}{l}\text { Implant failure (5); } \\
\text { infection (5); }\end{array}$ & NM & NM & NM & NM & NM \\
\hline
\end{tabular}

NM: not mention. AS after surgery 


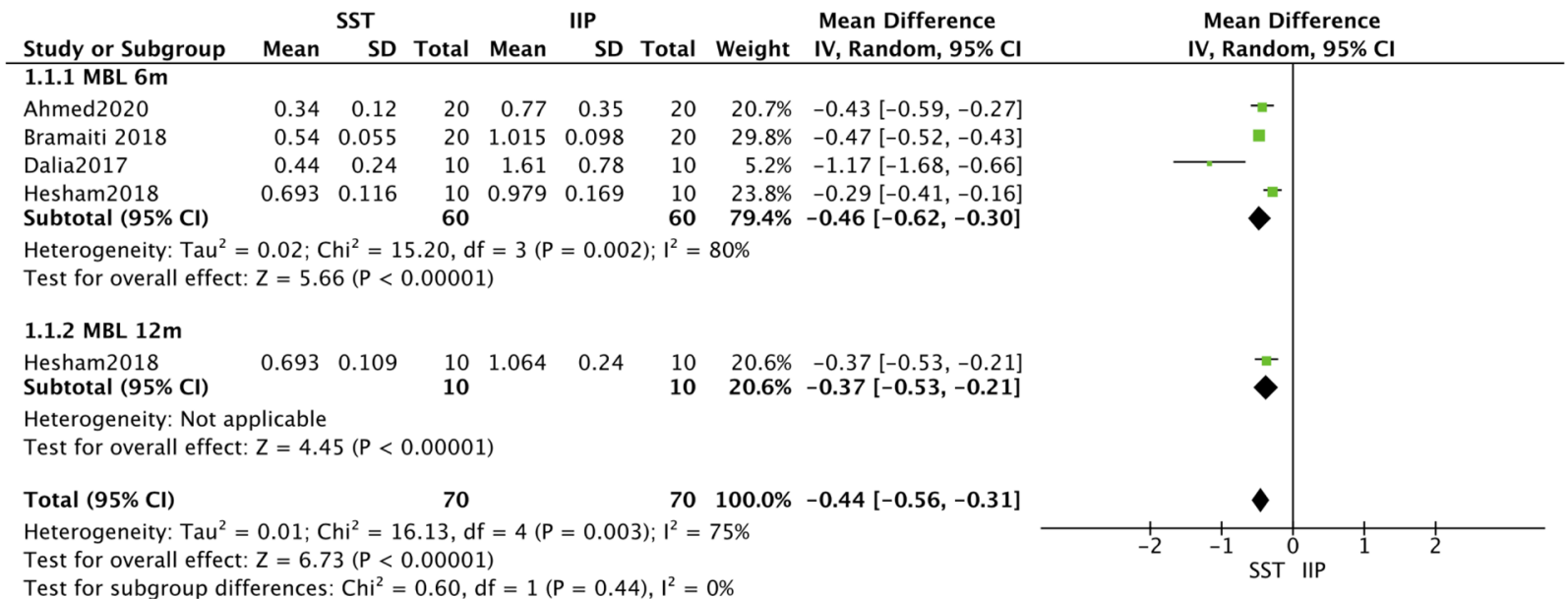

Fig. 2. Forest plot for the event 'marginal bone loss (MBL)'.

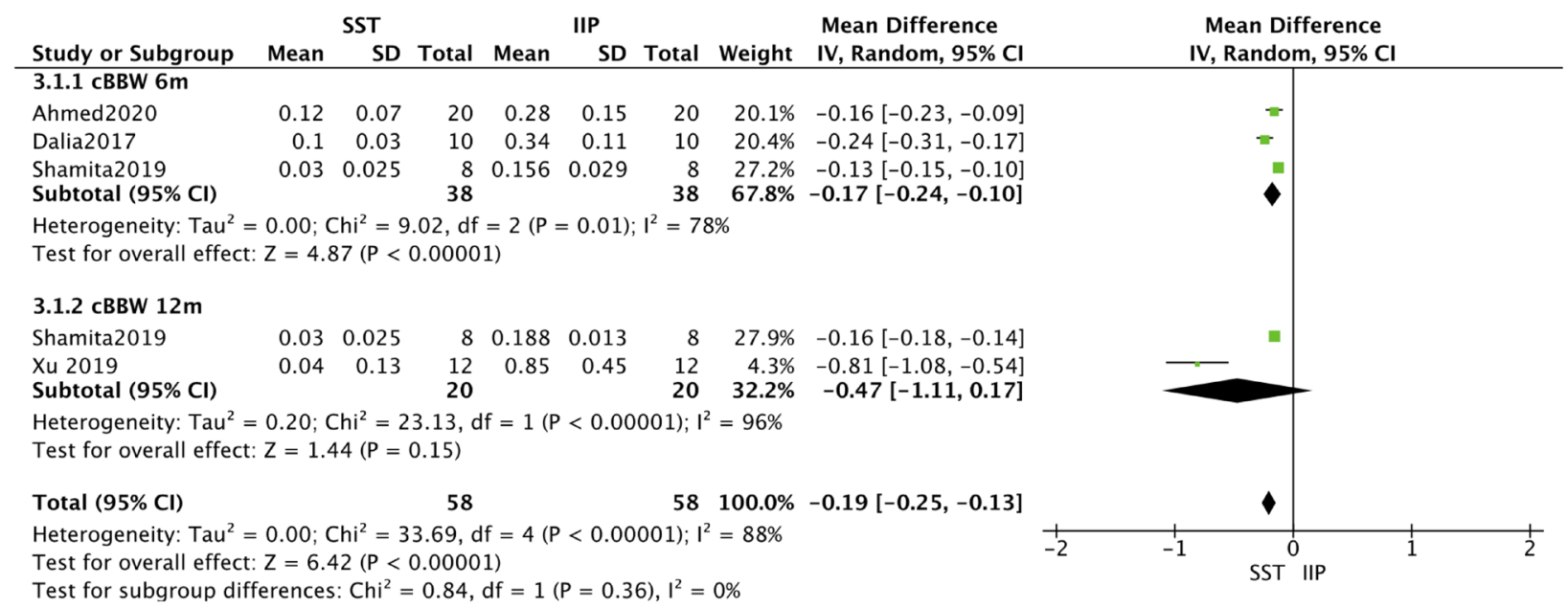

Fig. 3. Forest plot for the event 'changes in buccal bone width (cBBW)'.

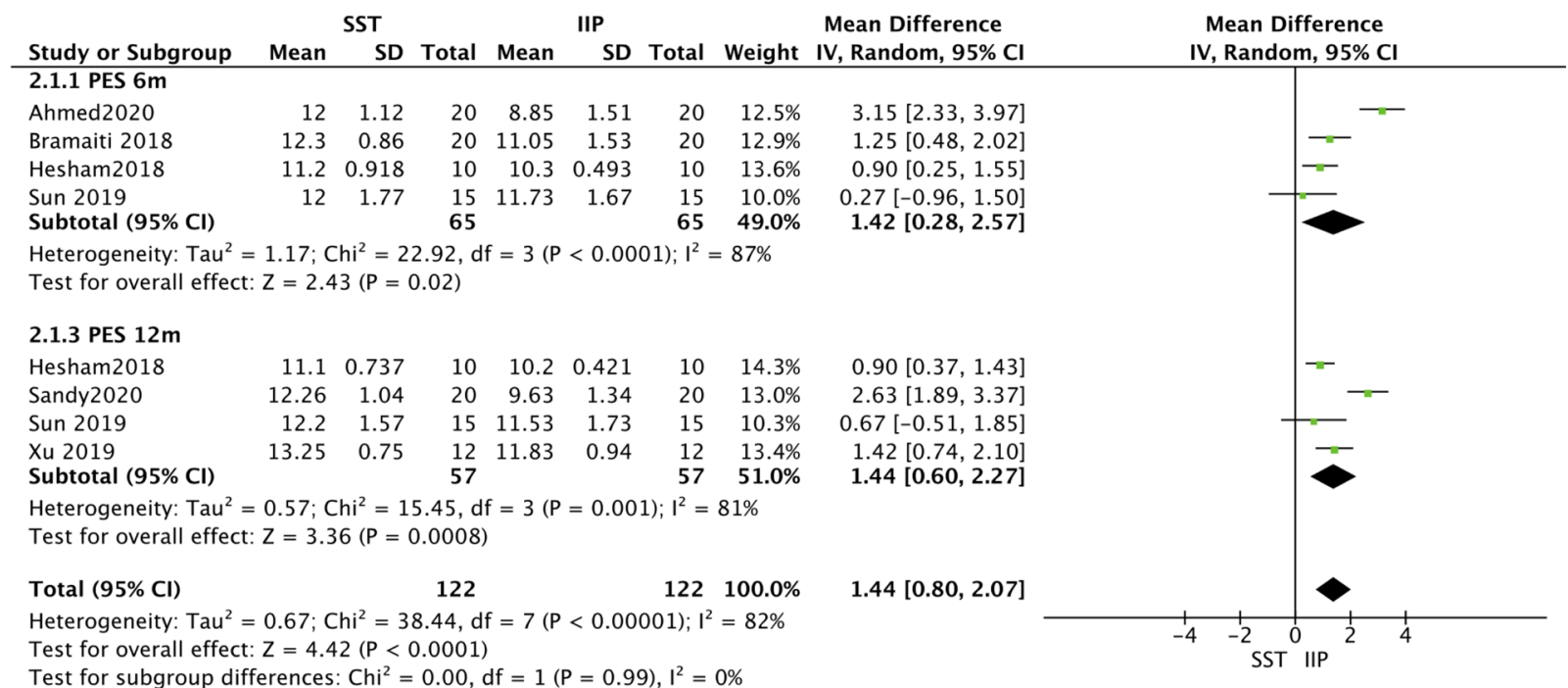

Fig. 4. Forest plot for the event 'pink esthetic score (PES)'. 


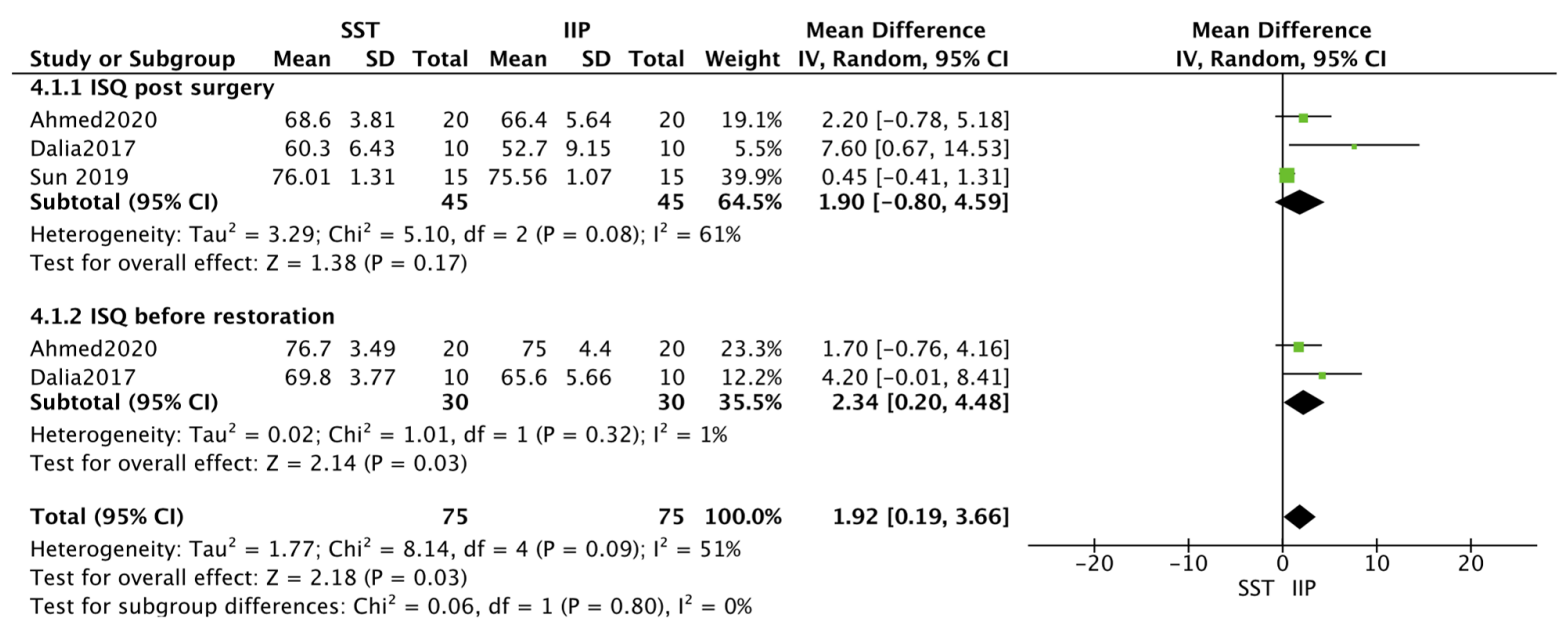

Fig. 5. Forest plot for the event 'implant stability quotient (ISQ)'.

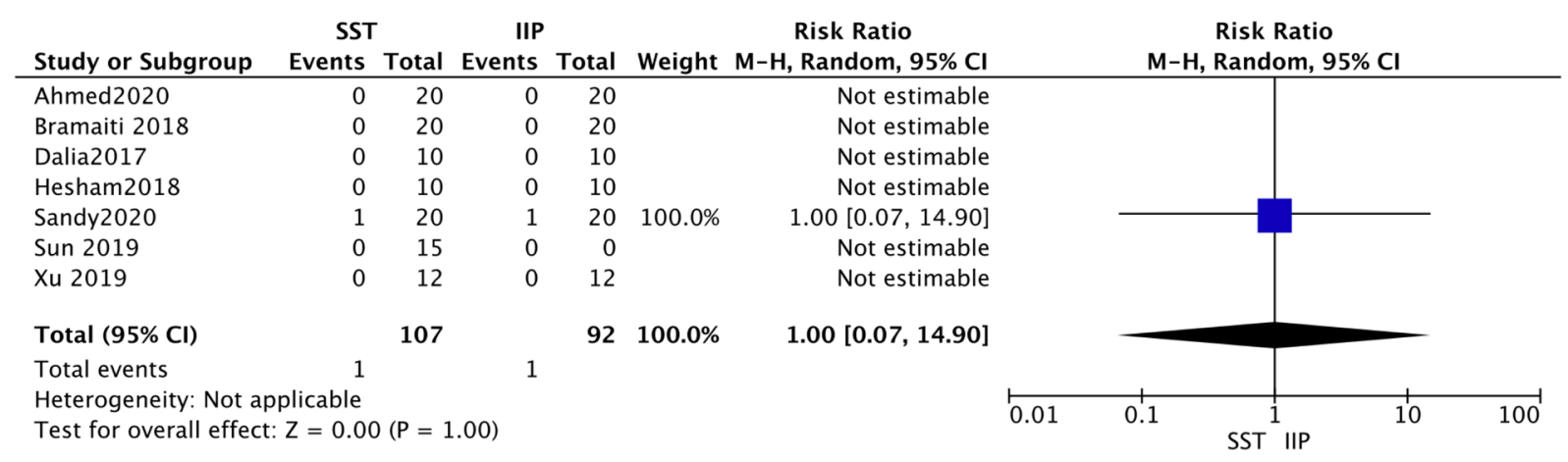

Fig. 6. Forest plot for the event 'implant failure'.

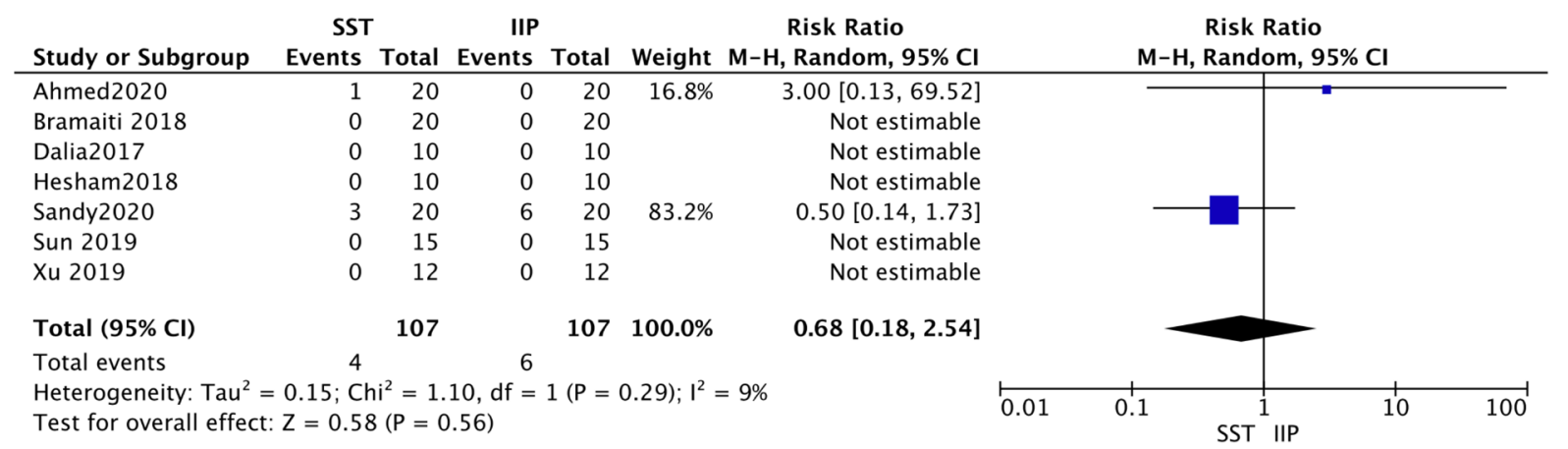

Fig. 7. Forest plot for the event 'complication'.

there is a lack of evidence-based consensus. There is, therefore, an urgent need for further studies with higher levels of evidence in this area.

\section{Conclusion}

The included studies provided evidence that SST may be a feasible treatment option. Nevertheless, this technique should not be used as a routine clinical protocol due to its sensitivity and lack of evidence-based consensus conclusions. There is an urgent need for additional studies in this area to provide higher levels of evidence.

\section{Acknowledgements}

The authors thank Dr Shulan Xu for her assistance in preparing this manuscript.

\section{Funding}

This work was supported by Science research cultivation program of stomatological hospital, Southern medical university (grant numbers:PY2019025). 


\section{References}

[1] Chappuis V, Araujo MG Buser D. Clinical relevance of dimensional bone and soft tissue alterations post-extraction in esthetic sites. Periodontol. 2000 2017; 73: $73-83$.

[2] Sbordone C, Toti P, Martuscelli R, Guidetti F, Ramaglia L Sbordone L. Retrospective volume analysis of bone remodeling after tooth extraction with and without deproteinized bovine bone mineral insertion. Clin Oral Implants Res 2016; 27: 1152-9.

[3] Botticelli D, Berglundh T Lindhe J. Hard-tissue alterations following immediate implant placement in extraction sites. J. Clin. Periodontol. 2004; 31: 820-8.

[4] Atieh MA, Payne AG, Duncan WJ, de Silva RK Cullinan MP. Immediate placement or immediate restoration/loading of single implants for molar tooth replacement: a systematic review and meta-analysis. Int J Oral Maxillofac Implants 2010; 25: 401-15.

[5] Demircan S Demircan E. Dental Cone Beam Computed Tomography Analyses of the Anterior Maxillary Bone Thickness for Immediate Implant Placement. Implant Dent 2015; 24: 664-8.

[6] Bittner N, Schulze-Späte U, Silva C, et al. Changes of the alveolar ridge dimension and gingival recession associated with implant position and tissue phenotype with immediate implant placement: A randomized controlled clinical trial. Int J Oral Implantol (Berl). 2019;12(4):469-80.

[7] Chen ST Buser D. Esthetic outcomes following immediate and early implant placement in the anterior maxilla--a systematic review. Int J Oral Maxillofac Implants 2014; 29 Suppl: 186-215.

[8] Hurzeler MB, Zuhr O, Schupbach P, Rebele SF, Emmanouilidis N Fickl S. The socket-shield technique: a proof-of-principle report. J. Clin. Periodontol. 2010 37: 855-62.

[9] Gharpure AS Bhatavadekar NB. Current Evidence on the Socket-Shield Technique: A Systematic Review. J. Oral Implantol 2017; 43: 395-403.

[10] Mourya A, Mishra SK, Gaddale R Chowdhary R. Socket-shield technique for implant placement to stabilize the facial gingival and osseous architecture: A systematic review. J Investig Clin Dent 2019; 10: e12449.

[11] Blaschke C Schwass DR. The socket-shield technique: a critical literature review. Int J Implant Dent 2020; 6: 52.

12] Cumpston M, Li T, Page MJ, Chandler J, Welch VA Higgins JP, et al. Updated guidance for trusted systematic reviews: a new edition of the Cochrane Handbook for Systematic Reviews of Interventions. Cochrane Database Syst Rev 2019; 10: D142.

[13] Syrene A. Miller BAJL. Enhancing your practice through evidence-based decision making: PICO, learning how to ask good questions. J. Evid-Based Dent Pr 2001; 1: 136-41.

[14] Munn Z, Barker TH, Moola S, Tufanaru C, Stern C McArthur A, et al. Methodological quality of case series studies: an introduction to the JBI critical appraisal tool. JBI Database System Rev Implement Rep 2019.

[15] Furhauser R, Florescu D, Benesch T, Haas R, Mailath G Watzek G. Evaluation of soft tissue around single-tooth implant crowns: the pink esthetic score. Clin Oral Implants Res 2005; 16: 639-44.

[16] Chen MH, Lyons K, Tawse-Smith A Ma S. Resonance Frequency Analysis in Assessing Implant Stability: A Retrospective Analysis. Int. J. Prosthodont. 2019; 32: 317-26.

[17] Bramanti E, Norcia A, Cicciu M, Matacena G, Cervino G Troiano G, et al. Postextraction Dental Implant in the Aesthetic Zone, Socket Shield Technique Versus Conventional Protocol. J. Craniofac. Surg. 2018; 29: 1037-41.

[18] Sun C, Zhao J, Liu Z, Tan L, Huang Y Zhao L, et al. Comparing conventional flap-less immediate implantation and socket-shield technique for esthetic and clinical outcomes: A randomized clinical study. Clin Oral Implants Res 2020; 31: $181-91$

[19] Abd-Elrahman A, Shaheen M, Askar N Atef M. Socket shield technique vs conventional immediate implant placement with immediate temporization. Randomized clinical trial. Clin Implant Dent Relat Res 2020.

[20] Barakat DA, S R Riham H. evaluation of the socket shield technique for immediate implantation. Alexandria Dental Journal 2017: 155-61.

[21] Xu Y, HHuang, Wang L, Wu Q, Gang F Li J. Comparison of clinical effects of a modified socket shield technique and the conventional immediate implant placement. West China Journal of Stomatology 2019; 31: 490-5

[22] Hesham F. Socket shield technique versus guided bone regeneration techinique for ridge preservation with immediate implant placement in the esthetic zone. Egyptian Dental Journal 2018; 64: 2048-55.

[23] Tiwari S, Bedi RS, Wadhwani P, Aurora JK Chauhan H. Comparison of Immediate Implant Placement Following Extraction with and Without SocketShield Technique in Esthetic Region. J. Maxillofac. Oral Surg. 2019.

[24] Hana SA Omar OA. Socket shield technique for dental implants in the Esthetic zone, clinical and radiographical evaluation. Journal of University of Duhok 2020; 23: 69-80.
[25] Yan S, Zhou C, J L, XN X, Y Y X C, et al. Clinical evaluation of the socketshield technique for immediate implantation in the maxillary anterior region. West China Journal of Stomatology 2019; 6: 615-20.

[26] Han CH, Park KB Mangano FG. The modified socket shield technique. J. Craniofac. Surg. 2018; 29: 2247-54.

[27] Baumer D, Zuhr O, Rebele S Hurzeler M. Socket Shield Technique for immediate implant placement - clinical, radiographic and volumetric data after 5 years. Clin Oral Implants Res 2017; 28: 1450-58.

[28] Hinze M, Janousch R, Goldhahn S Schlee M. Volumetric alterations around single-tooth implants using the socket-shield technique: preliminary results of a prospective case series. Int J Esthet Dent 2018; 13: 146-70.

[29] Siormpas KD, Mitsias ME, Kontsiotou-Siormpa E, Garber D Kotsakis GA. Immediate implant placement in the esthetic zone utilizing the "root-membrane" technique: clinical results up to 5 years postloading. Int J Oral Maxillofac Implants 2014; 29: 1397-405.

[30] Siormpas KD, Mitsias ME, Kotsakis GA, Tawil I, Pikos MA Mangano FG. The root membrane technique: a retrospective clinical study with up to 10 years of follow-up. Implant Dent 2018; 27: 564-74.

[31] Gluckman H, Salama M Du Toit J. A retrospective evaluation of 128 socketshield cases in the esthetic zone and posterior sites: Partial extraction therapy with up to 4 years follow-up. Clin Implant Dent Relat Res 2018; 20: 122-9.

[32] Zhu Y, Qiu L, Chen L, Gao M, Wei H Huang J. Clinical evaluation of socket shield technique in maxillay anterior region. Chinese Journal of Stomatology 2019; 53: 663-8.

[33] Shrier I, Boivin JF, Steele RJ, Platt RW, Furlan A Kakuma R, et al. Should meta-analyses of interventions include observational studies in addition to randomized controlled trials? A critical examination of underlying principles. Am. J. Epidemiol. 2007; 166: 1203-9.

[34] Zhuang J, Zhao D, Wu Y Xu C. Evaluation of Outcomes of Dental Implants Inserted by Flapless or Flapped Procedure: A Meta-Analysis. Implant Dent 2018; 27: 588-98.

[35] Canullo L, Fedele GR, Iannello G Jepsen S. Platform switching and marginal bone-level alterations: the results of a randomized-controlled trial. Clin Oral Implants Res 2010; 21: 115-21.

[36] Gluckman H, Salama M Du Toit J. Partial Extraction Therapies (PET) Part 1: Maintaining alveolar ridge contour at pontic and immediate implant sites. The International Journal of Periodontics \& Restorative Dentistry 2016; 36: 681-7.

[37] Tan Z, Kang J, Liu W Wang H. The effect of the heights and thicknesses of the remaining root segments on buccal bone resorption in the socket-shield technique: An experimental study in dogs. Clin Implant Dent Relat Res 2018; 20: 352-9

[38] Baumer D, Zuhr O, Rebele S, Schneider D, Schupbach P Hurzeler M. The socket-shield technique: first histological, clinical, and volumetrical observations after separation of the buccal tooth segment - a pilot study. Clin Implant Dent Relat Res 2015; 17: 71-82.

[39] Sculean A, Gruber R Bosshardt DD. Soft tissue wound healing around teeth and dental implants. J. Clin. Periodontol. 2014; 41 Suppl 15: S6-22.

[40] Abrahamsson I, Berglundh T Lindhe J. The mucosal barrier following abutment dis/reconnection. An experimental study in dogs. J. Clin. Periodontol. 1997; 24: 568-72.

[41] Chen J, Chiang C Zhang Y. Esthetic evaluation of natural teeth in anterior maxilla using the pink and white esthetic scores. Clin Implant Dent Relat Res 2018; 20: 770-7

[42] Bavetta G, Bavetta G, Randazzo V, Cavataio A, Paderni C Grassia V, et al. A retrospective study on insertion torque and implant stability quotient (ISQ) as stability parameters for immediate loading of implants in fresh extraction sockets. Biomed Res Int 2019; 2019: 9720419.

[43] Langer L, Langer B Salem D. Unintentional root fragment retention in proximity to dental implants: a series of six human case reports. Int J Periodontics Restorative Dent 2015; 35: 305-13.

[44] Nevins ML, Langer L Schupbach P. Late Dental Implant Failures Associated with Retained Root Fragments: Case Reports with Histologic and SEM Analysis. Int J Periodontics Restorative Dent 2018; 38: 9-15.

[45] Zuhr O, Staehler P Huerzeler M. Complication Management of a Socket Shield Case After 6 Years of Function. Int J Periodontics Restorative Dent 2020; 40: 409-15.

[46] Park SH, Sorensen WP Wang HL. Management and prevention of retrograde peri-implant infection from retained root tips: two case reports. Int $\mathrm{J}$ Periodontics Restorative Dent 2004; 24: 422-33.

[47] Gandhi Y Bhatavadekar N. Inappropriate socket shield protocol as a probable cause of peri-implant bone resorption: a case report. J Maxillofac Oral Surg 2020; 19: 359-63.

\section{(). (1) \&}

Copyright: This is an open-access article distributed under the terms of Creative Commons Attribution-NonCommercial License 4.0 (CC BY-NC 4.0), which allows users to distribute and copy the material in any format as long as credit is given to the Japan Prosthodontic Society. It should be noted however, that the material cannot be used for commercial purposes. 